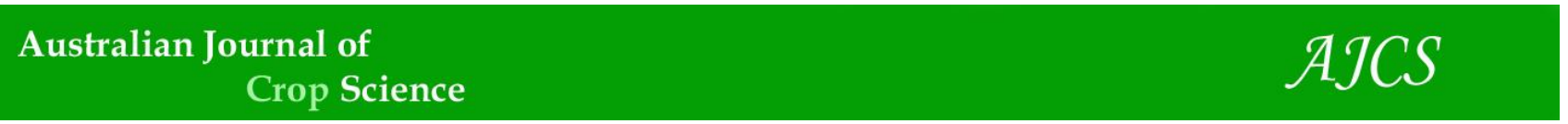

AJCS 15(01):119-128 (2021)

ISSN:1835-2707

doi: 10.21475/ajcs.21.15.01.2923

\title{
The potential of nutrient cycling in cover plants in response to phosphate
} fertilization

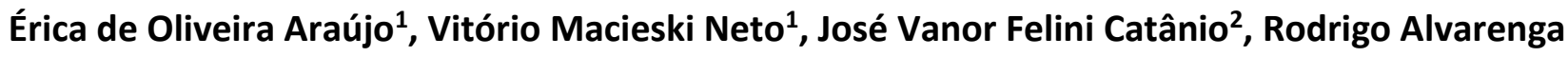 da Silva ${ }^{1}$, Nélio Ranieli Ferreira de Paula ${ }^{1}$, Diogo de Souza Freitas ${ }^{1}$, Jiovane Anderson da Silva Ribeiro $^{2}$, Daniele Jesus Venturim ${ }^{1}$}

\author{
${ }^{1}$ Department of Agriculture, Federal Institute of Education, Science and Technology, Rondonia State, \\ Campus Colorado do Oeste, Brazil \\ ${ }^{2}$ Department of Integration, Teaching, Research and Extension, Federal Institute of Education, Science \\ and Technology, Rondonia State, Campus Colorado do Oeste, Brazil
}

\section{*Corresponding author: erica.araujo@ifro.edu.br}

\begin{abstract}
Residues of crops and cover crops contain considerable amounts of phosphorus (P) in their tissues, which through their mineralization can meet much of the requirement of crops. In this context, the present study aimed to evaluate the biomass production, $\mathrm{P}$ absorption and use of different cover crops subjected to phosphate fertilization, and its effects on the absorption and use of nitrogen $(\mathrm{N})$, phosphorus $(\mathrm{P})$ and potassium $(\mathrm{K})$. The experiment was conducted in a protected environment from August to December 2019. The experimental design was completely randomized, arranged in a $7 \times 3$ scheme, consisting of the planting of seven species of cover crops (Crotalaria spectabilis, Crotalaria breviflora, Crotalaria ochroleuca, Mucuna aterrima, Mucuna pruriens, Dolichos lablab and Canavalia ensiformis), three $\mathrm{P}$ rates $\left(0,80\right.$ and $160 \mathrm{~kg} \mathrm{ha}^{-1}$ of $\left.\mathrm{P}_{2} \mathrm{O}_{5}\right)$ and four replicates. At the time of full flowering, the cover species were cut and divided into root and shoot for subsequent determination of dry mass production, nutrient content and absorption efficiency and nutrient utilization. The results showed that Canavalia ensiformis promoted higher yield of shoot fresh and dry mass, $\mathrm{P}$ content in the shoots and higher $\mathrm{N}$ and $\mathrm{P}$ absorption efficiency. $\mathrm{N}$ and $\mathrm{P}$ contents in Dolichos lablab roots were higher at the highest $\mathrm{P}$ rates $\left(160 \mathrm{~kg} \mathrm{ha}^{-1}\right.$ of $\left.\mathrm{P}\right)$, without close relationship with the supply of shoot dry mass. The $\mathrm{P}$ dose of $160 \mathrm{~kg} \mathrm{ha}^{-1}$ had an increasing and significant effect on the production of shoot fresh mass and dry mass, $\mathrm{N}, \mathrm{P}$ and $\mathrm{K}$ contents in the shoots, N, P and K contents in the roots and efficiency of N, P and K use by the different cover crops. The $\mathrm{P}$ rates of $80 \mathrm{~kg} \mathrm{ha}^{-1}$ increased the N, P and K contents in the shoots of Crotalaria ochroleuca, Crotalaria breviflora and Crotalaria spectabilis; and at higher $\mathrm{P}$ rates, there was a reduction in nutrient accumulation. The species Mucuna pruriens and Mucuna aterrima were efficient in the use of $\mathrm{N}, \mathrm{P}$ and $\mathrm{K}$ at $\mathrm{P}$ rates of $160 \mathrm{~kg} \mathrm{ha}^{-1}$.
\end{abstract}

Keywords: Green manure; Legume species; Nutrient cycling; Phosphorus; P use efficiency; Soil sustainable management.

Introduction

The supply of phosphorus $(\mathrm{P})$ represents a significant portion of the production cost of crops, especially in tropical regions, because in addition to having low $\mathrm{P}$ availability, almost all soils are weathered, acidic, clayey and oxidic, characteristics that favor P fixation by the soil (Silva et al., 2011). The practical implication of this is that, although $P$ requirement by plants is not high, large amounts of the nutrient must be supplied through fertilization to promote some soil saturation and originate a surplus that meets the nutritional requirements of crops (Novais and Smyth, 1999).

Most of the cost in the establishment of a plantation in the southern region of the Rondônia state is related to the correction of soil acidity and phosphate fertilization. Thus, considering the essentiality of $\mathrm{P}$ for plant development, and phosphates as a non-renewable natural resource, it is necessary to search for ways to use it efficiently. One practice that results in increased recovery of $\mathrm{P}$ added to the soil is the implementation of soil conservation practices, including species with high efficiency in extracting and using P. Based on this premise, plants that have structural, biochemical and physiological mechanisms enable a greater use of soil $P$, which can be used to achieve a high agronomic efficiency of phosphate fertilization (Fernandes and Muraoka, 2002)

Residues of crops and cover crops contain considerable amounts of $P$ in their tissues, which through their mineralization can meet much of the requirement of crops. In the process of mineralization of organic residues, organic forms of $P$ that are less susceptible to adsorption reactions are formed. The soil can adsorb organic acids with great energy, competing with the $\mathrm{P}$ adsorption sites and increasing 
the availability of this nutrient for plants (Oliveira et al., 2002; Andrade et al., 2003).

Studies have shown that plants with greater capacity to extract $P$ are those that have abundant root system and produce exudates capable of acidifying the rhizosphere, favoring the solubilization of the less reactive, waterinsoluble natural phosphates, when they need acidity for some dissolution. Another factor that favors the solubility of natural phosphates is the sink of $\mathrm{P}$ and $\mathrm{Ca}$ by plants. $\mathrm{A}$ greater removal of $\mathrm{Ca}$ and $\mathrm{P}$ increases the dissolution rate of natural phosphate (Silva et al., 2011). Thus, conditions that favor the increase cation exchange capacity (CEC) with a higher content of organic matter and liming, besides the crop itself, can play a major role in the efficiency of natural phosphates, as they would act as Ca sink (Silva et al., 2009). Together, $\mathrm{P}$ cycling by plants gains importance, because they have different levels of adaptation to access soil $P$ (Hall et al., 2010). it is essential to identify the ones with the greatest potential to absorb and cycle soil $\mathrm{P}$ and to optimize the use of soil $P$ by plants in agricultural systems, as the access mechanisms vary with the plant species, especially those that can be used commercially or as soil cover crops cultivated in succession and/or rotation with commercial species. The synchronization between plant species, soils and $P$ is an indispensable tool for the best use of this element by different species, maximizing the plant's response to phosphate fertilization in most tropical soils (Andrade et al., 2003; Soares et al., 2007).

Thus, studying the effect of different crop systems and soil managements on the forms of $P$ accumulation in soil is the way to select agricultural practices to improve the dynamics of this nutrient in soil and as a management alternative that contributes to the maintenance or improvement of soil quality. The indication of diversified cover crops associated with a system of crop succession and/or rotation in the Amazon Biome is relevant for the deepening of scientific knowledge and for a new technological process aimed at agricultural production in the Amazon region, with lower costs due to the reduction in the use of chemical fertilizers. In view of the above, the present study aimed to evaluate the biomass production, $\mathrm{P}$ absorption and use by different cover crops subjected to phosphate fertilization, and its effects on the absorption and use of N, P and K.

\section{Results and discussion}

The results showed significant effects $(p \leq 0.05)$ of the double interaction between cover crops and $\mathrm{P}$ rates on $\mathrm{N}, \mathrm{P}$ and $\mathrm{K}$ contents in the shoots (Table 6), N, P and $K$ contents in the root (Table 7) and efficiency of $\mathrm{N}, \mathrm{P}$ and $\mathrm{K}$ use (Table 8). However, the other results did not show significant effect of the interaction and are independently presented for the different cover crops (Table 3, 4 and 5 ) and $P$ rates (Figure 2, 3,4 and 5).

\section{Fresh and dry mass production Dry by cover crops}

Canavalia ensiformis was statistically superior $(p \leq 0.05)$ to the other cover crops in terms of shoot fresh and dry mass production, while root dry mass production had one of the lowest values recorded among the different cover crops (Table 3). It is observed that even with low root dry mass production, which may be closely related to the soil volume available for root development, Canavalia ensiformis was able to absorb the largest amount of $\mathrm{N}$ by the root (16.52g) $\mathrm{kg}^{-1}$ (Table 4). In contrast, lower amounts of $\mathrm{N}$ were accumulated in the shoots (Table 4), as an inverse relationship between the variables. Pereira et al. (2017), studied nutrient cycling by different cover plants and found that Canavalia ensiformis led to better results regarding shoot fresh and dry mass production at the phenological stage of flowering, while Bortoluzzi et al. (2019) verified that Canavalia ensiformis has high potential for biomass supply in different sowing periods. Barros et al. (2017) and Teodoro et al. (2011) suggested Canavalia ensiformis as an excellent cover species because it has rapid initial growth, large cotyledonary leaves, good soil cover and high dry mass production capacity, besides performing biological $\mathrm{N}$ fixation.

The lowest values of shoot fresh mass and dry mass production were verified for the cover crop Dolichos lablab (Table 3), with a direct correlation between shoot fresh and dry mass production and the lowest $\mathrm{N}$ accumulation in the shoots (17.72 $\mathrm{g} \mathrm{kg}^{-1}$ ) (Table 4). However, the species had the highest $P$ contents in the shoots $\left(1.66 \mathrm{~g} \mathrm{~kg}^{-1}\right)$, not differing statistically from Crotalaria breviflora and Crotalaria spectabilis (Table 4). N and P contents in Dolichos lablab roots were significantly higher than those found in the other cover plants, making it possible to infer the ability of this species to accumulate $\mathrm{N}$ and $\mathrm{P}$ in its root tissues, without close relationship with the supply of shoot dry mass.

Among the cover plants, for the production of root dry mass and total dry mass, the species Mucuna aterrima, Mucuna pruriens and Crotalaria ochroleuca stood out and did not differ statistically from one another (Table 3).

\section{Nutrient content in shoot and root by cover crops}

Regarding the $\mathrm{K}$ contents in shoots and roots, the species Crotalaria spectabilis was superior to the others, while the lowest $\mathrm{K}$ contents in shoots and roots were accumulated by Canavalia ensiformis (Table 4). $\mathrm{K}$ absorption by the respective cover crops ranged between $17.18 \mathrm{~g} \mathrm{~kg}^{-1}$ for Crotalaria spectabilis and $10.57 \mathrm{~g} \mathrm{~kg}^{-1}$ for Canavalia ensiformis. These significant $\mathrm{K}$ contents in the shoots of Crotalaria spectabilis corroborate those found by Pereira et al. (2017) and Mauad et al. (2019). In areas with low K levels, it is important to use soil cover plants due to their capacity for cycling, accumulation and supply of nutrients to subsequent crops, favoring the entire agricultural system (Teodoro et al., 2011). The difference of response between species regarding the production and absorption of nutrients is confirmed in the literature, due to the existence of nutritional behavior differentiated by genetic factors of adaptability. In terms of $\mathrm{N}$ and $\mathrm{P}$ absorption efficiency, Canavalia ensiformis stood out with values of 65.45 for $\mathrm{N}$ absorption and in the order of 4.43 for $\mathrm{P}$ absorption, $\mathrm{mg}$ of dry weight per $\mathrm{g}$ of $\mathrm{N}$ and $\mathrm{P}$ absorbed, not differing statistically from the species Crotalaria breviflora and Crotalaria spectabilis (Table 5). This higher efficiency of $\mathrm{N}$ and $\mathrm{P}$ absorption by Canavalia ensiformis tended to follow the shoot dry mass production, but it was not correlated with the highest $\mathrm{N}$ contents in the shoots (Table 3 and 4). The species Crotalaria breviflora and Crotalaria spectabilis besides being efficient in the absorption of $\mathrm{N}$ and $\mathrm{P}$ were significantly efficient in terms of $\mathrm{K}$ absorption (Table 5). 
These data corroborate the $\mathrm{K}$ contents found in the roots of both species (Table 4). It is important to highlight that, in addition to the capacity of the species, as a legume crop to fix atmospheric $\mathrm{N}$ by the symbiotic association with bacteria of the genus Rhizobium, they have high efficiency for cycling and immobilization of nutrients. In the same premise of nutrient absorption efficiency, Canavalia ensiformis had the highest efficiency in the use of nutrients, such as $P$ and $K$ (Table 5). Thus, it is possible to affirm that the efficiency of $P$ absorption by the species is directly correlated with the $P$ use efficiency, but the $\mathrm{K}$ use efficiency is not consistent with the $\mathrm{K}$ absorption efficiency. This information points out Canavalia ensiformis as an alternative for adaptation to different edaphoclimatic conditions, soils of low fertility as it can absorb the nutrients from deeper layers, and use them in the shoots.

The species Mucuna pruriens and Mucuna aterrima were significantly efficient regarding the use of $\mathrm{N}, \mathrm{P}$ and $\mathrm{K}$ (Table $5)$. The branched and deep root systems of these legume crops promote an increase in the efficiency of fertilizer use, since they bring up to the surface soil layer nutrients that had been lost by leaching, mainly potassium, calcium, magnesium and nitrate. They also functioning as a 'mining agent' of nutrients of low availability such as $P$, enabling them more available to subsequent crops (Padovam et al., 2011). In addition to the root system morphology, the efficiency of $P$ use per root unit, the acid phosphatase activity and $\mathrm{P}$ contents in the roots and shoots explain the dynamics of $\mathrm{P}$ absorption and acquisition by the different cover crop species. Barros et al. (2017), evaluated the nutrient extraction and potential of different plant species, aiming at the supply of nutrients to the subsequent crop. They verified that Mucuna aterrima had the highest accumulations of all macronutrients, especially $\mathrm{N}, \mathrm{P}, \mathrm{K}$ and $\mathrm{Mg}$, which demonstrates the high capacity of the species in the absorption and use of nutrients.

\section{Fresh and dry mass production in response to phosphorous rates}

$P$ doses exerted an increasing and significant effect $(p \leq 0.05)$ on the production of shoot fresh mass (Figure 2A), shoot dry mass (Figure 2B), root dry mass (Figure $2 \mathrm{C}$ ) and total dry mass (Figure 2D) of the different cover crops. The highest yields were obtained at a $\mathrm{P}$ dose of $160 \mathrm{~kg} \mathrm{ha}^{-1}$, which reveals a positive effect of phosphate fertilization on the growth and development of cover crops. This demonstrates that theses crops are very efficient in the use of soil $P$ from mineral phosphate fertilization. In the present study, triple superphosphate was used as source of $P$. It is known that the reactivity characteristics of $P$ sources are extremely important in relation to their short-term efficiency. Phosphates of greater reactivity, being more readily available, which favored the absorption and use of the nutrient by plants (Silva et al., 2011). Another aspect is that the higher availability of $\mathrm{P}$ can trigger changes in photosynthesis, due to the greater capture of solar radiation and increase in the production of photoassimilates, because $P$ acts as a forming agent of the ATP molecule and, under conditions of low ATP production, plant growth is directly affected (Rocha, 2016). In the present study, the P content in the soil considering the clay percentage was $5 \mathrm{mg} \mathrm{dm}^{-3}$. This is considered very low, which justifies the increasing response of the variables shoot and total dry mass production as a function of increasing doses of $\mathrm{P}_{2} \mathrm{O}_{5}$ applied at sowing.

\section{Nutritional content and efficiency in response to phosphorous rates}

The $\mathrm{N}$ contents in the shoots (Figure $3 \mathrm{~A}$ ) and in the root (Figure $4 A$ ) responded significantly $(p \leq 0.05)$ to the increment of $P$ doses, with maximum $\mathrm{N}$ contents in leaves and roots of $22.90 \mathrm{~g} \mathrm{~kg}^{-1}$ and $12.55 \mathrm{~g} \mathrm{~kg}^{-1}$, respectively. At the $\mathrm{P}$ rates of $160 \mathrm{~kg} \mathrm{ha}^{-1}$, they were statistically different from the control treatment and from the $P$ rates of $80 \mathrm{~kg} \mathrm{ha}^{-1}$. This increase in leaf and root $\mathrm{N}$ contents with the application of phosphate fertilization corroborates the higher efficiency of $\mathrm{N}$ use by cover plants $\left(7.03 \mathrm{~g} \mathrm{mg}^{-1}\right.$ ) (Figure $\left.5 \mathrm{~A}\right) . \mathrm{N}$ is one of the nutrients that most limit plant growth in the tropics. Therefore, the use of green manures capable of efficiently performing biological $\mathrm{N}$ fixation can represent considerable contributions to the economic viability and sustainability of production systems (Boddey et al., 1997), through the total or partial replacement of the $\mathrm{N}$ fertilization of the subsequent crop.

For $\mathrm{P}$ and $\mathrm{K}$ contents in shoots and roots, there was no significant difference between the $P$ rates of 80 and $160 \mathrm{~kg}$ $\mathrm{ha}^{-1}$ applied at sowing (Figure $3 \mathrm{~B}, 3 \mathrm{C}, 4 \mathrm{~B}, 4 \mathrm{C}$ ), but the $\mathrm{P}$ and $\mathrm{K}$ use efficiencies were higher at the $P$ rates of $160 \mathrm{~kg} \mathrm{ha}^{-1}$. The values were $94.3 \mathrm{~g} \mathrm{mg}^{-1}$ and $16.55 \mathrm{~g} \mathrm{mg}^{-1}$, respectively, differing statistically from the control treatment and from the $P$ rates of $80 \mathrm{~kg} \mathrm{ha}^{-1}$ (Figure $5 \mathrm{~B}$ and $5 \mathrm{C}$ ). From the data, it is possible to infer that there were increments in $\mathrm{P}$ and $\mathrm{K}$ use efficiency of $31 \%$ and $106 \%$, respectively, compared to the control ( $0 \mathrm{~kg} \mathrm{ha}^{-1}$ of $\left.\mathrm{P}\right)$, under $\mathrm{P}$ dose of $160 \mathrm{~kg} \mathrm{ha}^{-1}$ was applied.

\section{Unfolding of the interaction between cover crops and phosphorous rates}

The analysis of the double interaction was carried out with the objective of quantifying the nutrients recycled by the cover species, without considering phosphate fertilization $(0$ $\mathrm{kg} \mathrm{ha}^{-1}$ of P). We found that Crotalaria ochroleuca, Crotalaria breviflora and Crotalaria spectabilis were statistically superior to the other cover crops in the accumulation of $\mathrm{N}, \mathrm{P}$ and $\mathrm{K}$ in the shoots; thus, promoting the potential return of nutrients to the soil through biomass mineralization (Table 6). At $P$ rates of $80 \mathrm{~kg} \mathrm{ha}^{-1}$, the above-mentioned species continued to respond positively to phosphate fertilization by increasing the contents of $\mathrm{N}, \mathrm{P}$ and $\mathrm{K}$ in their tissues, differing statistically $(p<0.05)$ from the control $\left(0 \mathrm{~kg} \mathrm{ha}^{-1}\right.$ of $P)$. At higher $P$ rates, there was a reduction in the accumulation of nutrients in the shoots, although there was no statistically significant difference between the $P$ rates of 80 and $160 \mathrm{~kg} \mathrm{ha}^{-1}$ (Table 6). The average increase in $\mathrm{N}, \mathrm{P}$ and $\mathrm{K}$ contents in the shoots for Crotalaria ochroleuca, Crotalaria breviflora and Crotalaria spectabilis were on the order of $18.50 \%, 16.55 \%$ and $12.63 \%$, respectively, when compared to the control treatment and fertilized with $80 \mathrm{~kg}$ ha $^{-1}$ of $P$. Thus, the positive effect of phosphate fertilization is evident at moderate $P$ rates and the species of crotalaria have significant tolerance to soils of low fertility and with low levels of $P$.

We observed that Dolichos lablab, Mucuna pruriens, 
Table 1. Chemical attributes of the soil before installing the experiment at different depths.

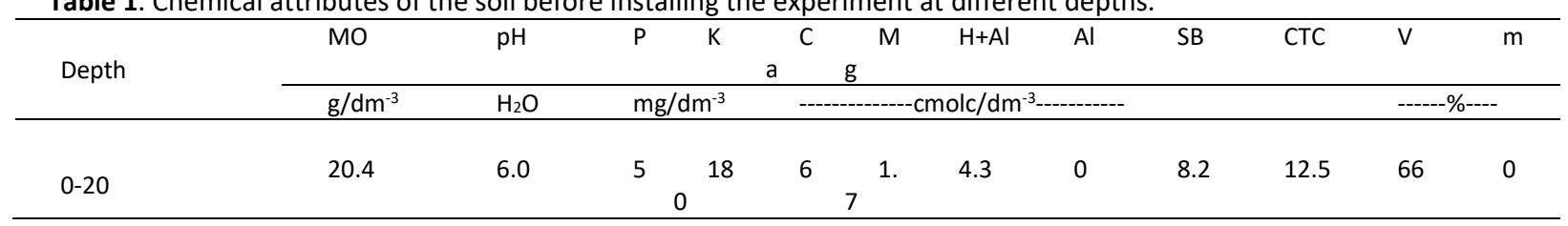

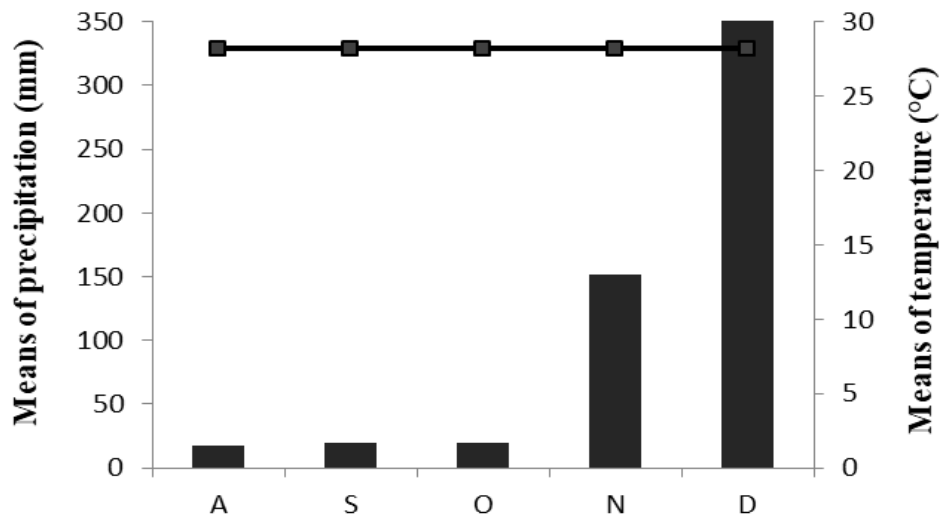

Monthly

Fig 1. Monthly means of precipitation $(\mathrm{mm})$ and temperature $\left({ }^{\circ} \mathrm{C}\right)$, recorded in the weather station of the National Institute of Meteorology, from August to December of the 2019 agricultural year.

Table 2. Species of cover crops (treatments of plots) and their respective $\mathrm{C} / \mathrm{N}$ ratios indicated in the literature.

\begin{tabular}{lll}
\hline \multicolumn{1}{c}{ Species } & Family & C/N ratio \\
\hline Crotalaria ochroleuca & Fabaceae & $25-29^{2}$ \\
Crotalaria spectabilis & Fabaceae & $10-16^{1}$ \\
Crotalaria breviflora & Fabaceae & $11-18$ \\
Mucuna aterrima & Fabaceae & $12-21^{1}$ \\
Mucuna pruriens & Fabaceae & $12-21^{1}$ \\
Dolichos lablab & Fabaceae & $23-28^{3}$ \\
Canavalia ensiformis & Fabaceae & $10-16^{1}$ \\
\hline
\end{tabular}

A

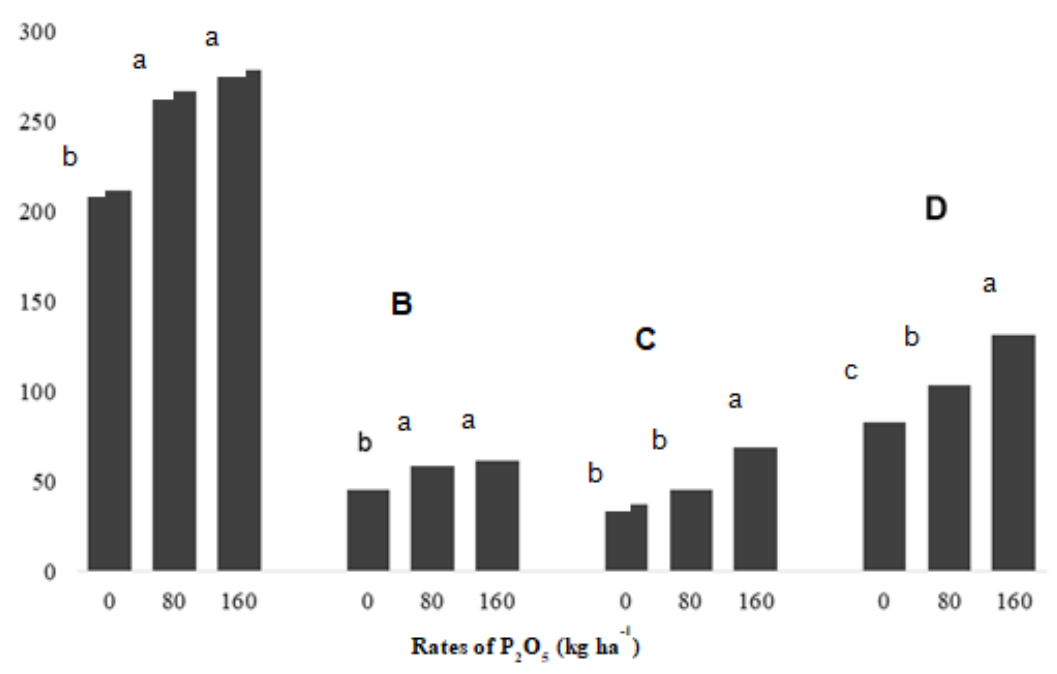

A (Shoot fresh mass (g)), B (Shoot dry mass (g)), C (Root dry mass (g)) and $\mathbf{D}$ (Total dry mass (g))

Fig 2. Production of shoot fresh mass (A), shoot dry mass (B), root dry mass (C) and total dry mass (D) of cover crops in response to phosphate fertilization. Means followed by the same letter on the bars do not differ statistically by Tukey test at $5 \%$ probability level. 
Table 3. Shoot fresh mass (SFM), shoot dry mass (SDM), root dry mass (RDM) and total dry mass (TDM) of different cover crops cultivated in protected environment.

\begin{tabular}{lllll}
\hline Cover crops & SFM & $\begin{array}{c}\text { SDM } \\
\left.\text { (g.vase }{ }^{-1}\right)\end{array}$ & RDM & TDM \\
\cline { 2 - 5 } & $310.26 \mathrm{a}$ & $77.05 \mathrm{a}$ & $32.06 \mathrm{c}$ & $109.11 \mathrm{bc}$ \\
Canavalia ensiformis & $219.53 \mathrm{c}$ & $45.59 \mathrm{~d}$ & $43.95 \mathrm{~b}$ & $93.54 \mathrm{~cd}$ \\
Dolichos lablab & $223.29 \mathrm{c}$ & $57.97 \mathrm{~b}$ & $83.80 \mathrm{a}$ & $141.78 \mathrm{a}$ \\
Mucuna pruriens & $236.91 \mathrm{bc}$ & $59.59 \mathrm{~b}$ & $74.27 \mathrm{a}$ & $133.86 \mathrm{ab}$ \\
Mucuna aterrima & $256.25 \mathrm{bc}$ & $51.65 \mathrm{~d}$ & $66.44 \mathrm{a}$ & $118.10 \mathrm{abc}$ \\
Crotalaria ochroleuca & $249.30 \mathrm{bc}$ & $45.48 \mathrm{~d}$ & $25.44 \mathrm{c}$ & $70.92 \mathrm{~d}$ \\
Crotalaria breviflora & $271.38 \mathrm{~b}$ & $49.60 \mathrm{~d}$ & $28.11 \mathrm{c}$ & $75.72 \mathrm{~d}$ \\
Crotalaria spectabilis & 12.53 & 13.38 & 29.93 & 21.52 \\
\hline CV (\%) & &
\end{tabular}

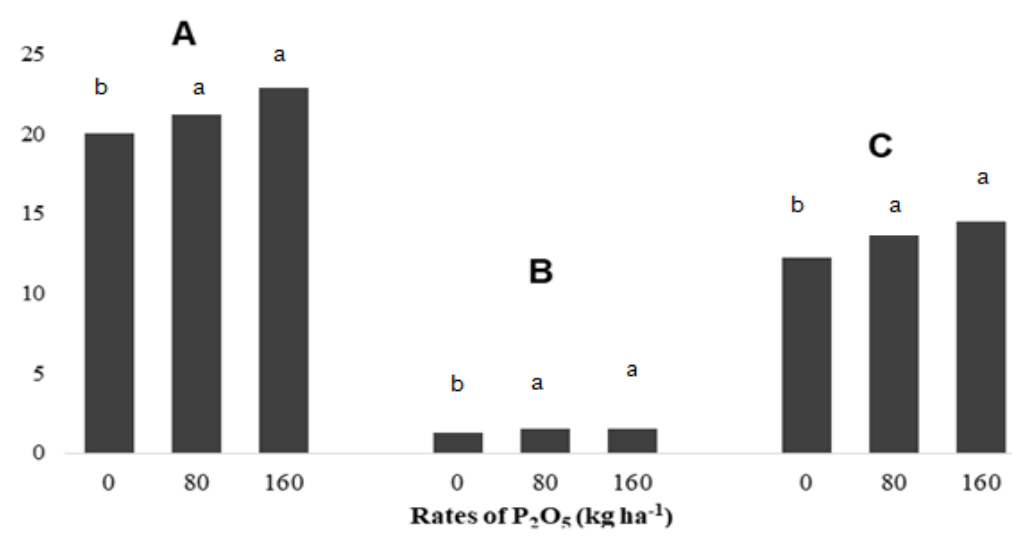

A $(\mathrm{N}$ content in the shoots $(\mathrm{g} / \mathrm{kg})), \mathbf{B}(\mathrm{P}$ content in the shoots $(\mathrm{g} / \mathrm{kg}))$ and $\mathrm{C}(\mathrm{K}$ content in the shoots $(\mathrm{g} / \mathrm{kg}))$

Fig 3. $N$ content in the shoots (A), $P$ content in the shoots (B) and $K$ content in the shoots (C) of cover plants in response to phosphate fertilization. Means followed by the same letter on the bars do not differ statistically by Tukey's test at $5 \%$ probability level.

Table 4. Nitrogen content in the shoots $(\mathrm{N})$, phosphorus content in the shoots $(\mathrm{P})$, potassium content in the shoots $(\mathrm{K})$, nitrogen content in the root (NR), phosphorus content in the root (PR) and potassium content in the root (KR) of different cover crops cultivated in protected environment.

\begin{tabular}{|c|c|c|c|}
\hline \multirow[t]{2}{*}{ Cover crops } & $\mathrm{N}$ & $\mathrm{P}$ & K \\
\hline & \multicolumn{3}{|c|}{$\mathrm{g} / \mathrm{kg}^{-1}$} \\
\hline Canavalia ensiformis & $19.15 \mathrm{c}$ & $1.16 \mathrm{c}$ & $10.57 \mathrm{e}$ \\
\hline Dolichos lablab & $17.72 \mathrm{c}$ & $1.66 \mathrm{a}$ & $13.72 b$ \\
\hline Mucuna pruriens & $21.65 \mathrm{~b}$ & $1.19 \mathrm{c}$ & $11.43 \mathrm{e}$ \\
\hline Mucuna aterrima & $22.69 \mathrm{~b}$ & $1.28 \mathrm{c}$ & $12.63 \mathrm{~d}$ \\
\hline Crotalaria ochroleuca & $26.64 \mathrm{a}$ & $1.46 \mathrm{~b}$ & $15.29 \mathrm{~b}$ \\
\hline Crotalaria breviflora & $22.62 b$ & $1.57 \mathrm{a}$ & $14.08 \mathrm{~b}$ \\
\hline Crotalaria spectabilis & $21.46 \mathrm{~b}$ & $1.62 \mathrm{a}$ & $17.18 \mathrm{a}$ \\
\hline CV (\%) & 8.21 & 9.74 & 9.75 \\
\hline \multirow[t]{2}{*}{ Cover crops } & NR & PR & $\mathrm{KR}$ \\
\hline & \multicolumn{3}{|c|}{$\mathrm{g} / \mathrm{kg}^{-1}$} \\
\hline Canavalia ensiformis & $16.52 \mathrm{a}$ & $1.32 \mathrm{bc}$ & $7.15 \mathrm{c}$ \\
\hline Dolichos lablab & $14.07 \mathrm{ab}$ & $1.54 \mathrm{a}$ & $7.75 \mathrm{c}$ \\
\hline Mucuna pruriens & $15.24 \mathrm{ab}$ & $1.27 \mathrm{bc}$ & $7.28 \mathrm{c}$ \\
\hline Mucuna aterrima & $15.11 \mathrm{a}$ & $1.26 \mathrm{c}$ & $8.80 \mathrm{~b}$ \\
\hline Crotalaria ochroleuca & $14.14 a b$ & $1.15 \mathrm{~d}$ & $4.88 \mathrm{~d}$ \\
\hline Crotalaria breviflora & $13.02 \mathrm{~b}$ & $1.34 \mathrm{bc}$ & $11.18 \mathrm{a}$ \\
\hline Crotalaria spectabilis & $15.25 \mathrm{ab}$ & $1.37 \mathrm{~b}$ & $11.79 \mathrm{a}$ \\
\hline $\mathrm{CV}(\%)$ & 12.22 & 6.37 & 21.22 \\
\hline
\end{tabular}

Means followed by the same letter in the column do not differ statistically by Tukey's test at 5\% probability level. CV (Coefficient of variation). 


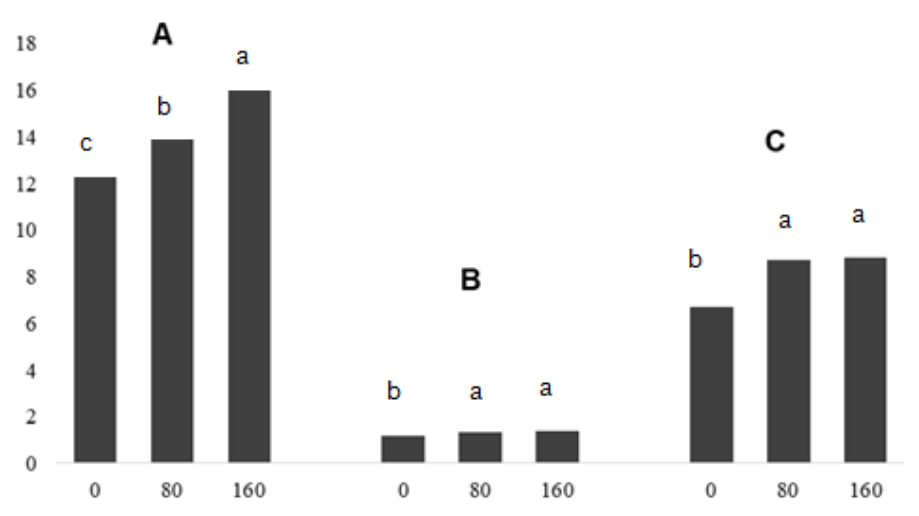

Rates of $\mathrm{P}_{2} \mathrm{O}_{5}\left(\mathrm{~kg} \mathrm{ha}^{-1}\right)$

A ( $\mathrm{N}$ content in the root $(\mathrm{g} / \mathrm{kg}))$, B (P content in the root $(\mathrm{g} / \mathrm{kg}))$ and

$\mathrm{C}(\mathrm{K}$ content in the root $(\mathrm{g} / \mathrm{kg}))$

Fig 4. $\mathrm{N}$ content in the root (A), $\mathrm{P}$ content in the root (B) and $\mathrm{K}$ content in the root (C) of cover plants in response to phosphate fertilization. Means followed by the same letter on the bars do not differ statistically by Tukey's test at $5 \%$ probability level.

Table 5. Efficiency of absorption and use of macronutrients by different cover crops cultivated in a protected environment.

\begin{tabular}{|c|c|c|c|}
\hline \multirow[t]{2}{*}{ Cover crops } & \multicolumn{2}{|c|}{$\begin{array}{r}\text { Efficiency of absorption } \\
\mathrm{mg} \mathrm{g}^{-1}\end{array}$} & \multirow[b]{2}{*}{$\mathrm{K}$} \\
\hline & $\mathrm{N}$ & $\mathrm{P}$ & \\
\hline Canavalia ensiformis & $65.45 \mathrm{a}$ & $4.43 \mathrm{a}$ & $28.49 \mathrm{bc}$ \\
\hline Dolichos lablab & $36.08 \mathrm{~cd}$ & $3.59 \mathrm{~b}$ & $24.23 b c$ \\
\hline Mucuna pruriens & $33.36 \mathrm{~d}$ & $2.27 \mathrm{c}$ & $16.46 \mathrm{c}$ \\
\hline Mucuna aterrima & $36.17 \mathrm{~cd}$ & $2.44 \mathrm{bc}$ & $20.18 \mathrm{c}$ \\
\hline Crotalaria ochroleuca & $44.02 \mathrm{~cd}$ & $2.82 \mathrm{bc}$ & $24.39 \mathrm{bc}$ \\
\hline Crotalaria breviflora & $57.44 a b$ & $4.47 \mathrm{a}$ & $39.01 \mathrm{a}$ \\
\hline Crotalaria spectabilis & $53.77 \mathrm{ab}$ & $4.37 \mathrm{a}$ & $42.29 a$ \\
\hline $\mathrm{CV}(\%)$ & 30.76 & 28.63 & 30.80 \\
\hline \multirow{3}{*}{ Cover crops } & \multirow{2}{*}{\multicolumn{2}{|c|}{ Efficiency of use }} & \\
\hline & & & \\
\hline & $\mathrm{N}$ & $P$ & K \\
\hline Canavalia ensiformis & $6.11 \mathrm{~b}$ & $92.00 \mathrm{a}$ & $11.04 \mathrm{a}$ \\
\hline Dolichos lablab & $5.81 \mathrm{~b}$ & $57.56 \mathrm{~b}$ & $6.64 \mathrm{~b}$ \\
\hline Mucuna pruriens & $8.20 \mathrm{a}$ & $114.75 \mathrm{a}$ & $10.79 a$ \\
\hline Mucuna aterrima & $7.14 \mathrm{a}$ & $106.26 \mathrm{a}$ & $14.35 \mathrm{a}$ \\
\hline Crotalaria ochroleuca & $5.87 \mathrm{~b}$ & $92.26 \mathrm{a}$ & $5.09 \mathrm{~b}$ \\
\hline Crotalaria breviflora & $3.80 \mathrm{c}$ & $48.22 \mathrm{~b}$ & $4.22 \mathrm{~b}$ \\
\hline Crotalaria spectabilis & $3.98 \mathrm{c}$ & $49.37 \mathrm{~b}$ & $4.10 \mathrm{~b}$ \\
\hline CV (\%) & 26.48 & 23.49 & 38.76 \\
\hline
\end{tabular}

Means followed by the same letter in the column do not differ statistically by Tukey's test at 5\% probability level. CV (Coefficient of variation).

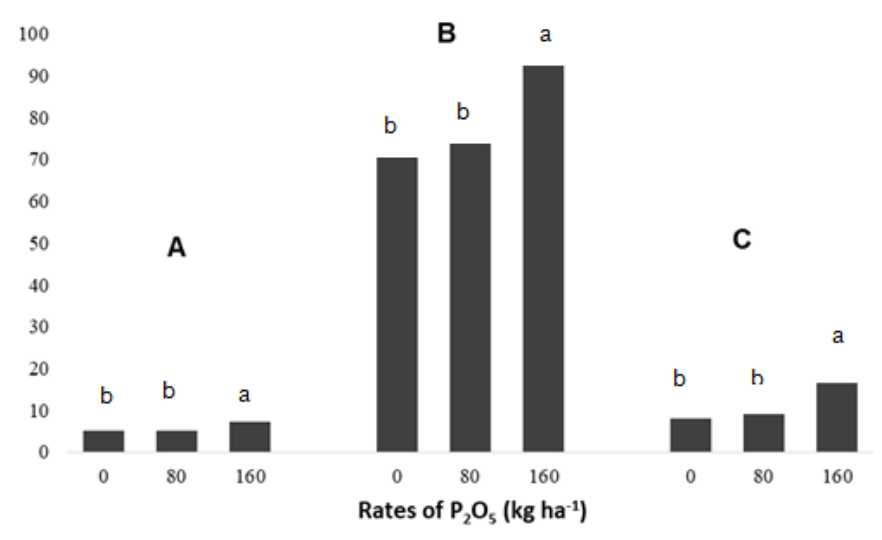

A (N use efficiency (g.mg-1), B (P use efficiency $\left(\mathrm{g}_{\mathrm{mg}}-^{1}\right)$ and

C (K use efficiency $\left(\mathrm{g} \cdot \mathrm{mg}^{1}\right)$

Fig 5. $\mathrm{N}$ use efficiency (A), P use efficiency (B) and $K$ use efficiency $(C)$ by cover plants in response to phosphate fertilization. Means followed by the same letter on the bars do not differ statistically by Tukey's test at $5 \%$ probability level.

Table 6. Analysis of the interaction between cover plants and phosphorus doses for nitrogen, phosphorus and potassium contents 
in the shoots.

\begin{tabular}{|c|c|c|c|}
\hline \multirow{3}{*}{ Cover crops } & \multicolumn{3}{|c|}{$\mathrm{N}$ content in the shoots $\left(\mathrm{g} / \mathrm{kg}-{ }^{1}\right)$} \\
\hline & \multicolumn{3}{|c|}{ Rates of $\mathrm{P}_{2} \mathrm{O}_{5}\left(\mathrm{~kg} \mathrm{ha}^{-1}\right)$} \\
\hline & 0 & 80 & 160 \\
\hline Canavalia ensiformis & $17.53 \mathrm{cdA}$ & $19.55 \mathrm{bA}$ & $20.36 \mathrm{bcA}$ \\
\hline Dolichos lablab & $16.78 \mathrm{dA}$ & $18.12 \mathrm{bA}$ & $18.26 \mathrm{cA}$ \\
\hline Mucuna pruriens & $18.36 \mathrm{cdB}$ & $23.63 \mathrm{abA}$ & $22.97 \mathrm{bA}$ \\
\hline Mucuna aterrima & $21.84 \mathrm{abB}$ & $25.22 \mathrm{aA}$ & $21.02 \mathrm{bcB}$ \\
\hline Crotalaria ochroleuca & $23.70 \mathrm{aB}$ & $26.77 \mathrm{aA}$ & $29.43 \mathrm{aA}$ \\
\hline Crotalaria breviflora & $21.18 \mathrm{abB}$ & $25.62 \mathrm{aA}$ & $21.08 \mathrm{bcB}$ \\
\hline \multirow[t]{2}{*}{ Crotalaria spectabilis } & $20.62 \mathrm{abcB}$ & $25.41 \mathrm{aA}$ & $22.36 \mathrm{bB}$ \\
\hline & \multicolumn{3}{|c|}{$\mathrm{P}$ content in the shoots $\left(\mathrm{g} / \mathrm{kg}^{-}{ }^{1}\right)$} \\
\hline \multirow[t]{2}{*}{ Cover crops } & \multicolumn{3}{|c|}{ Rates of $\mathrm{P}_{2} \mathrm{O}_{5}\left(\mathrm{~kg} \mathrm{ha}^{-1}\right)$} \\
\hline & 0 & 80 & 160 \\
\hline Canavalia ensiformis & $0.90 \mathrm{bB}$ & $1.26 \mathrm{dA}$ & $1.32 \mathrm{cA}$ \\
\hline Dolichos lablab & $1.49 \mathrm{aB}$ & $1.66 \mathrm{abAB}$ & $1.84 \mathrm{aA}$ \\
\hline Mucuna pruriens & $0.98 \mathrm{bB}$ & $1.31 \mathrm{cdA}$ & $1.28 \mathrm{cA}$ \\
\hline Mucuna aterrima & $0.96 \mathrm{bB}$ & $1.41 \mathrm{cdA}$ & $1.48 \mathrm{bcA}$ \\
\hline Crotalaria ochroleuca & $1.35 \mathrm{aB}$ & $1.61 \mathrm{abA}$ & $1.51 \mathrm{bcA}$ \\
\hline Crotalaria breviflora & $1.62 \mathrm{aA}$ & $1.60 \mathrm{abA}$ & $1.48 \mathrm{bcB}$ \\
\hline \multirow[t]{2}{*}{ Crotalaria spectabilis } & $1.39 \mathrm{aB}$ & $1.86 \mathrm{aA}$ & $1.61 \mathrm{abB}$ \\
\hline & \multicolumn{3}{|c|}{$\mathrm{K}$ content in the shoots $\left(\mathrm{g} / \mathrm{kg}^{-1}\right)$} \\
\hline \multirow[t]{2}{*}{ Cover crops } & \multicolumn{3}{|c|}{ Rates of $\mathrm{P}_{2} \mathrm{O}_{5}\left(\mathrm{~kg} \mathrm{ha}^{-1}\right)$} \\
\hline & 0 & 80 & 160 \\
\hline Canavalia ensiformis & $10.75 \mathrm{cA}$ & $12.65 \mathrm{cA}$ & $11.33 \mathrm{bcA}$ \\
\hline Dolichos lablab & $11.93 \mathrm{cC}$ & $15.64 \mathrm{abA}$ & $13.59 \mathrm{bB}$ \\
\hline Mucuna pruriens & 9.98 cB & $12.45 \mathrm{cA}$ & $8.86 \mathrm{cB}$ \\
\hline Mucuna aterrima & $12.21 \mathrm{bcA}$ & $13.61 \mathrm{bcA}$ & $12.05 \mathrm{bA}$ \\
\hline Crotalaria ochroleuca & $18.80 \mathrm{aA}$ & $15.56 \mathrm{abB}$ & $11.49 \mathrm{bcc}$ \\
\hline Crotalaria breviflora & $15.05 \mathrm{aA}$ & $14.35 \mathrm{abA}$ & $12.83 \mathrm{bB}$ \\
\hline Crotalaria spectabilis & $19.12 \mathrm{aA}$ & $17.12 \mathrm{aAB}$ & $15.31 \mathrm{aB}$ \\
\hline
\end{tabular}

Table 7. Analysis of the interaction between cover crops and phosphorus doses for nitrogen, phosphorus and potassium contents in the root.

\begin{tabular}{|c|c|c|c|}
\hline \multirow{3}{*}{ Cover crops } & \multicolumn{3}{|c|}{$\mathrm{K}$ content in the root $\left(\mathrm{g} / \mathrm{kg}^{-}{ }^{1}\right)$} \\
\hline & \multicolumn{3}{|c|}{ Rates of $\mathrm{P}_{2} \mathrm{O}_{5}\left(\mathrm{~kg} \mathrm{ha}^{-1}\right)$} \\
\hline & 0 & 80 & 160 \\
\hline Canavalia ensiformis & $10.23 \mathrm{bB}$ & $18.02 \mathrm{aA}$ & $18.32 \mathrm{aA}$ \\
\hline Dolichos lablab & $13.66 \mathrm{aA}$ & $14.18 \mathrm{bA}$ & $14.38 \mathrm{bA}$ \\
\hline Mucuna pruriens & $13.61 \mathrm{aB}$ & $18.51 \mathrm{aA}$ & $13.59 \mathrm{bcB}$ \\
\hline Mucuna aterrima & $13.82 \mathrm{aC}$ & $18.25 \mathrm{aA}$ & $16.27 \mathrm{abB}$ \\
\hline Crotalaria ochroleuca & $9.53 \mathrm{bC}$ & $17.14 \mathrm{abA}$ & $15.74 \mathrm{abB}$ \\
\hline Crotalaria breviflora & $13.17 \mathrm{aAB}$ & $15.55 \mathrm{abA}$ & $10.33 \mathrm{cB}$ \\
\hline \multirow[t]{2}{*}{ Crotalaria spectabilis } & $13.87 \mathrm{aB}$ & $16.36 \mathrm{abA}$ & $15.53 \mathrm{abA}$ \\
\hline & \multicolumn{3}{|c|}{$\mathrm{P}$ content in the shoots $\left(\mathrm{g} / \mathrm{kg}^{-1}\right)$} \\
\hline \multirow[t]{2}{*}{ Cover crops } & \multicolumn{3}{|c|}{ Rates of $\mathrm{P}_{2} \mathrm{O}_{5}\left(\mathrm{~kg} \mathrm{ha}^{-1}\right)$} \\
\hline & 0 & 80 & 160 \\
\hline Canavalia ensiformis & $1.09 \mathrm{cB}$ & $1.39 \mathrm{bA}$ & $1.48 \mathrm{abA}$ \\
\hline Dolichos lablab & $1.36 \mathrm{aB}$ & $1.63 \mathrm{aA}$ & $1.64 \mathrm{aA}$ \\
\hline Mucuna pruriens & $1.22 \mathrm{bA}$ & $1.34 \mathrm{bA}$ & $1.25 \mathrm{cdA}$ \\
\hline Mucuna aterrima & $1.05 \mathrm{cB}$ & $1.34 \mathrm{bA}$ & $1.38 \mathrm{bcA}$ \\
\hline Crotalaria ochroleuca & $1.18 \mathrm{bA}$ & $1.10 \mathrm{cA}$ & $1.16 \mathrm{dA}$ \\
\hline Crotalaria breviflora & $1.34 \mathrm{aA}$ & $1.29 \mathrm{bA}$ & $1.39 \mathrm{bcA}$ \\
\hline \multirow[t]{2}{*}{ Crotalaria spectabilis } & $1.22 \mathrm{cB}$ & $1.41 \mathrm{bA}$ & $1.49 \mathrm{abA}$ \\
\hline & \multicolumn{3}{|c|}{$\mathrm{K}$ content in the root $\left(\mathrm{g} / \mathrm{kg}{ }^{1}\right)$} \\
\hline \multirow[t]{2}{*}{ Cover crops } & \multicolumn{3}{|c|}{ Rates of $\mathrm{P}_{2} \mathrm{O}_{5}\left(\mathrm{~kg} \mathrm{ha}^{-1}\right)$} \\
\hline & 0 & 80 & 160 \\
\hline Canavalia ensiformis & $6.48 \mathrm{cA}$ & $8.87 \mathrm{bA}$ & $7.17 \mathrm{abA}$ \\
\hline Dolichos lablab & 7.91 bcA & $8.00 \mathrm{bA}$ & $5.53 \mathrm{bcA}$ \\
\hline Mucuna pruriens & $7.77 \mathrm{bcAB}$ & 9.11 bA & $4.96 \mathrm{bcB}$ \\
\hline Mucuna aterrima & $6.69 \mathrm{bcB}$ & $11.32 \mathrm{aA}$ & $8.39 \mathrm{abB}$ \\
\hline Crotalaria ochroleuca & 7.49 bcA & $4.27 \mathrm{cB}$ & $2.87 \mathrm{cB}$ \\
\hline Crotalaria breviflora & $12.87 \mathrm{aA}$ & $10.86 \mathrm{aB}$ & $9.81 \mathrm{aB}$ \\
\hline Crotalaria spectabilis & $10.36 \mathrm{abA}$ & $10.70 \mathrm{aA}$ & $8.32 \mathrm{abB}$ \\
\hline
\end{tabular}


Table 8. Analysis of the interaction between cover crops and phosphorus doses for the efficiency of use $\mathrm{N}$, efficiency of use $\mathrm{P}$ and efficiency of use K.

\begin{tabular}{|c|c|c|c|}
\hline \multirow{3}{*}{ Cover crops } & \multicolumn{3}{|c|}{ Efficiency of use nitrogen (g.mg- ${ }^{1}$ ) } \\
\hline & \multicolumn{3}{|c|}{ Rates of $\mathrm{P}_{2} \mathrm{O}_{5}\left(\mathrm{~kg} \mathrm{ha}^{-1}\right)$} \\
\hline & 0 & 80 & 160 \\
\hline Canavalia ensiformis & $6.76 \mathrm{abA}$ & $5.72 \mathrm{aA}$ & $6.86 \mathrm{bcA}$ \\
\hline Dolichos lablab & $4.30 \mathrm{bcB}$ & $6.00 \mathrm{aAB}$ & 7.14 bA \\
\hline Mucuna pruriens & $6.18 \mathrm{abB}$ & $5.85 \mathrm{aB}$ & $12.57 \mathrm{aA}$ \\
\hline Mucuna aterrima & $7.47 \mathrm{aA}$ & $6.47 \mathrm{aA}$ & $7.50 \mathrm{bA}$ \\
\hline Crotalaria ochroleuca & $3.86 \mathrm{cC}$ & $5.29 \mathrm{aB}$ & $8.46 \mathrm{bA}$ \\
\hline Crotalaria breviflora & $3.25 \mathrm{cA}$ & $3.36 \mathrm{bA}$ & $4.79 \mathrm{cA}$ \\
\hline \multirow[t]{2}{*}{ Crotalaria spectabilis } & $3.65 \mathrm{cA}$ & $3.53 \mathrm{bA}$ & $4.76 \mathrm{cA}$ \\
\hline & \multicolumn{3}{|c|}{ Efficiency of use $P\left(\right.$ g.mg- $\left.{ }^{1}\right)$} \\
\hline \multirow[t]{2}{*}{ Cover crops } & \multicolumn{3}{|c|}{ Rates of $\mathrm{P}_{2} \mathrm{O}_{5}\left(\mathrm{~kg} \mathrm{ha}^{-1}\right)$} \\
\hline & 0 & 80 & 160 \\
\hline Canavalia ensiformis & $105.11 \mathrm{aA}$ & $85.54 a b B$ & $85.35 \mathrm{cB}$ \\
\hline Dolichos lablab & $46.45 \mathrm{cA}$ & $59.12 \mathrm{cdA}$ & $67.11 \mathrm{dA}$ \\
\hline Mucuna pruriens & $91.55 \mathrm{abB}$ & $92.08 \mathrm{abB}$ & $160.61 \mathrm{aA}$ \\
\hline Mucuna aterrima & $95.57 \mathrm{abA}$ & $101.15 \mathrm{aA}$ & $122.06 \mathrm{aA}$ \\
\hline Crotalaria ochroleuca & $51.38 \mathrm{bcC}$ & $89.50 \mathrm{abB}$ & $135.92 \mathrm{bA}$ \\
\hline Crotalaria breviflora & 39.29 cA & $49.54 \mathrm{dA}$ & $55.83 \mathrm{dA}$ \\
\hline \multirow[t]{2}{*}{ Crotalaria spectabilis } & $48.04 \mathrm{cA}$ & $40.38 \mathrm{dA}$ & $59.70 \mathrm{dA}$ \\
\hline & \multicolumn{3}{|c|}{ Efficiency of use $\mathrm{K}\left(\mathrm{g} \cdot \mathrm{mg}^{-1}\right.$ ) } \\
\hline \multirow[t]{2}{*}{ Cover crops } & \multicolumn{3}{|c|}{ Rates of $\mathrm{P}_{2} \mathrm{O}_{5}\left(\mathrm{~kg} \mathrm{ha}^{-1}\right)$} \\
\hline & 0 & 80 & 160 \\
\hline Canavalia ensiformis & $11.04 \mathrm{abA}$ & $9.46 \mathrm{aA}$ & $11.65 \mathrm{bA}$ \\
\hline Dolichos lablab & $6.64 \mathrm{abA}$ & $7.91 \mathrm{aA}$ & $12.39 \mathrm{bA}$ \\
\hline Mucuna pruriens & $10.79 \mathrm{abB}$ & $12.27 \mathrm{aB}$ & $33.41 \mathrm{aA}$ \\
\hline Mucuna aterrima & $14.35 \mathrm{aA}$ & $11.50 \mathrm{aA}$ & $13.70 \mathrm{bA}$ \\
\hline Crotalaria ochroleuca & $5.09 \mathrm{abB}$ & $11.75 \mathrm{aB}$ & $30.22 \mathrm{aA}$ \\
\hline Crotalaria breviflora & $4.22 \mathrm{bA}$ & $5.67 \mathrm{aA}$ & $7.01 \mathrm{bA}$ \\
\hline Crotalaria spectabilis & $4.10 \mathrm{bA}$ & $4.72 \mathrm{aA}$ & $7.47 \mathrm{bA}$ \\
\hline
\end{tabular}

Mucuna aterrima, Crotalaria breviflora and Crotalaria spectabilis were statistically superior to the other cover crops in terms of $\mathrm{N}$ accumulation in the root, in the absence of phosphate fertilization (Table 7). After, fertilization with $80 \mathrm{~kg} \mathrm{ha}^{-1}$ of $\mathrm{P}$, the species Mucuna pruriens and Mucuna aterrima responded to phosphate by increasing the $\mathrm{N}$ contents in the roots by $36 \%$ and $32 \%$, respectively, compared to the non-fertilized control statistically $(p<0.05)$ from the $P$ rates of $160 \mathrm{~kg} \mathrm{ha}^{-1}$ of $P$. The greatest increment in $\mathrm{K}$ content in the root was observed for Mucuna aterrima, Crotalaria breviflora and Crotalaria spectabilis at $\mathrm{P}$ rates of $80 \mathrm{~kg} \mathrm{ha}^{-1}$ (Table 7). Regarding the P contents in the root, Dolichos lablab had the highest increment of the nutrient in comparison to the control, at the highest $P$ rate $\left(160 \mathrm{~kg} \mathrm{ha}^{-1}\right.$ of $\mathrm{P})$ (Table 7), corroborating the results found individually for the species, as shown in Table 4. The species Mucuna pruriens and Mucuna aterrima were significantly efficient regarding the use of $N, P$ and $K$ at $P$ dose of $160 \mathrm{~kg} \mathrm{ha}^{-1}$ (Table 8), corroborating the results found and presented in Table 5 and Figure 5, besides having the highest root dry mass production, which gives these species greater root volume.

However, the use of these soil cover crops for green manure in crop succession or rotation systems has a great capacity to supply significant amounts of dry mass to the soil. The cycling and accumulation of nutrients in the shoots can reduce the use of chemical fertilizers applied in the subsequent crop and contribute to the development of a more sustainable agriculture in the Amazon region, with the premise of preserving the production environment.

\section{Material and Methods}

\section{Experimental area}

The experiment was conducted in a protected environment from August to December 2019, in the experimental area of the Federal Institute of Education, Science and Technology of Rondônia, Campus of Colorado do Oeste, in the municipality of Colorado do Oeste, RO, Brazil, at geographic coordinates of $13^{\circ} 06^{\prime} \mathrm{S}$ and $60^{\circ} 29^{\prime} \mathrm{W}$, with an average altitude of 407 meters. According to Köppen's classification, the climate is Awa, tropical hot and humid, with two welldefined seasons. Mean data of temperature and precipitation along the experiment were obtained from the National Institute of Meteorology (Inmet) database. Chemical characterization of the soil was performed in the 0 $20 \mathrm{~cm}$ layer, in samples collected before installing the experiment (Table 1).

\section{Experimental design}

The experimental design was completely randomized, arranged in a $7 \times 3$ scheme, consisting of the planting of seven species of cover crops (Crotalaria spectabilis, Crotalaria breviflora, Crotalaria ochroleuca, Mucuna aterrima, Mucuna pruriens, Dolichos lablab and Canavalia ensiformis) (Table 2), three $P$ rates $\left(0,80\right.$ and $160 \mathrm{~kg} \mathrm{ha}^{-1}$ of $\left.\mathrm{P}_{2} \mathrm{O}_{5}\right)$, using triple superphosphate (TSP) as soluble source of $\left.\begin{array}{lll}\mathrm{P}_{2} \mathrm{O}_{5} & (45 \% & \mathrm{P}_{2} \mathrm{O}_{5}\end{array}\right)$, and four replicates, totaling 84 experimental units. The amount of each $P$ dose was calculated based on the total $\mathrm{P}_{2} \mathrm{O}_{5}$ content of phosphate fertilizers, and converted to pot conditions. 


\section{Experimental methods}

Concomitantly with $\mathrm{P}$ application, basal fertilization with $\mathrm{N}$ and $\mathrm{K}$ was performed at doses of $30 \mathrm{~kg} \mathrm{ha}^{-1}$ of $\mathrm{N}$ and $60 \mathrm{~kg}$ ha $^{-1}$ of $\mathrm{K}_{2} \mathrm{O}$, using urea $(45 \% \mathrm{~N})$ and potassium chloride $(56 \%$ $\mathrm{K}_{2} \mathrm{O}$ ), respectively, incorporated into the soil for better standardization. The experimental units were composed of plastic pots with a capacity of $10 \mathrm{dm}^{-3}$, filled with air-dried soil, passed through a 4-mm-mesh sieve. The $P$ rates converted to the volume of experimental unit were 0.40 and $0.80 \mathrm{mg} \mathrm{dm}^{-3}$, while those of $\mathrm{N}$ and $\mathrm{K}$ corresponded to 0.015 and $0.03 \mathrm{mg} \mathrm{dm}^{-3}$, respectively. Moisture level of pots was controlled daily, always aiming to maintain the soil with $60 \%$ of field capacity. The seeds were placed to germinate directly in the pots eight days after emergence (DAE). Thinning was performed, leaving only one plant per experimental unit, considering the vigor and uniformity of the seedlings. Upon the full flowering of the cover species, the different plant parts were cut and divided into roots and shoots, and all the collected plant material was washed in running water and deionized water, weighed to determine the fresh mass. They subsequently dried in a forced air circulation oven at $65{ }^{\circ} \mathrm{C}$ for 72 hours, and then weighed again to determine the dry mass. After the plant material was dried and weighed, shoot and root dry masses were ground in a Wiley-type mill, and the samples were subjected to sulfuric digestion to determine $\mathrm{N}$ contents and to nitricperchloric digestion to determine $\mathrm{P}$ and $\mathrm{K}$ contents in the different plant parts (roots and shoot), according to the methodology described in Embrapa (2009).

The indices of nutrient absorption efficiency, ratio between the total nutrient content in the plant and root dry mass, were calculated according to Swiader et al. (1994), while the indices of nutrient use, ratio between the total dry mass produced and the total nutrient content in the plant were calculated according to Siddiqi and Glass (1981).

\section{Statistically analyzed}

The data were subjected to the normality test (Shapiro-Wilk) and analysis of variance. The effects between cover plants and $\mathrm{P}$ doses were evaluated by Tukey test at $5 \%$ probability level, and the correlations between the variables were determined using the statistical program Sisvar.

\section{Conclusions}

Canavalia ensiformis provided higher yield of shoot fresh and dry mass, $\mathrm{P}$ content in the shoots and higher $\mathrm{N}$ and $\mathrm{P}$ absorption efficiency. $\mathrm{N}$ and $\mathrm{P}$ contents in Dolichos lablab roots were higher at the highest $P$ rate (160 kg ha-1 of $P$ ), without close relationship with the supply of shoot dry mass. The $P$ rate of $160 \mathrm{~kg} \mathrm{ha}^{-1}$ exerted an increasing and significant effect on shoot fresh mass and dry mass production, $\mathrm{N}, \mathrm{P}$ and $\mathrm{K}$ contents in the shoots, $\mathrm{N}, \mathrm{P}$ and $\mathrm{K}$ contents in the root and $\mathrm{N}, \mathrm{P}$ and $\mathrm{K}$ use efficiency by the different cover crops. The $\mathrm{P}$ rate of $80 \mathrm{~kg} \mathrm{ha}^{-1}$ increased the $\mathrm{N}, \mathrm{P}$ and $\mathrm{K}$ contents in the shoots of Crotalaria ochroleuca, Crotalaria breviflora and Crotalaria spectabilis. At a higher $\mathrm{P}$ rate, there was a reduction in the accumulation of nutrients. The species Mucuna pruriens and Mucuna aterrima were efficient regarding the use of $\mathrm{N}, \mathrm{P}$ and $\mathrm{K}$ at $\mathrm{P}$ rate of $160 \mathrm{~kg}$ $\mathrm{ha}^{-1}$. The use of these cover crops is a potential method to improve nutrient dynamics in soil and an alternative management that contributes to the maintenance and improvement of soil quality in the Amazon biome.

\section{Acknowledgments}

The authors thank the Federal Institute of Rondonia and the National Council for Scientific and Technological Development for the provision of resources and scientific initiation grants.

\section{References}

Andrade FV, Mendonça ES, Alvarez VVH, Novais RF (2003) Addition of organic and humic acids in Latosols and phosphate adsorption. J Bra Soil Sci. 22:1003-1011.

Barros DL, Gomide PHO, Carvalho GJ (2013) Cover plants and their effects on culture in succession. Biosc J. 29:308318.

Boddey RM, Sa JC M, Alves BJR, Urquiaga SC (1997) The contribution of biological nitrogen fixation for sustainable agricultural systems in the tropics. Soil Biol and Bio. 29: 787-799.

Bortoluzzi MP, Heldwein AB, Leonardi M, Hinnah FD, Loose LH (2019) Growth, accumulation of phytomass and productivity of the pig bean at different sowing dates. Amaz J Agric and Env Sci. 62:1-7.

Brazilian Agricultural Research Company - Embrapa. (2009) Manual of chemical analyses of soils, plants and fertilizers. 2. Ed, Brasília., Embrapa Technological Information, pp.627.

Fernandes C, Muraoka T (2002) Phosphorus absorption by corn hybrids cultivated in cerrado soils. Scie Agri. 59:781787.

Hall H, Li Y, Comerford N, Gardini EA, Cernades LZ, Baligar V, Popenoe H (2010) Cover crops alter phosphorus soil fractions and organic matter accumulation in a Peruvian cacao agroforestry system. Agro Syst. 80: 447-455.

Mauad M, Santana RS, Carli TH, Carli F, Vitorino ACT, Mussury M, Rech, J (2019) Dry matter production and nutrient accumulation in Crotalaria spectabilis shoots. J Plant Nut. 42: 615-625.

Novais RF, Smyth TJ (1999) Phosphorus in soil and plant under tropical conditions. Viçosa, MG: UFV, DPS, pp.399.

Oliveira FHT, Novais RF, Alvarez VVH, Cantarutti RB, Barros NF (2002) Soil fertility in the no-tillage system. Top Soil Sci. 2: 393-486.

Padovan MP, Motta IS, Carneiro LF, Moitinho MR, Fernandes SSL (2011) Accumulation of phytomass and nutrients and the most adequate management stage of pig bean for green fertilization purposes. J Bra Agro. 6:182190.

Pereira AP, Schoffel A, Koefender J, Camera JN, Golle DP, Horn RC (2017) Nutrient cycling by summer cover plants. J Agrarian Sci. 40: 799-807.

Rocha W S (2016) Inoculation and phosphorus doses in cowpea in southern Tocantins State. Gurupi: UFT, pp.56. Dissertation (Master) - Postgraduate course in Agronomy, Concentration Area in Plant Production, Federal University of Tocantins, Gurupi. 
Siddiqi MY, Glass ADM (1981) Utilization índex: a modified approach to the estimations and comparison of nutrient utilization efficiency in plants. J Plant Nut. 4: 289-302.

Silva TO, Furtini Neto AE, Carneiro LF, Paludo V (2011) Cover crops submitted to different sources of phosphorus in different soils. Sem Agrarian Sci. 32: 1315-1326.

Silva FN, Furtini Neto AE, Carneiro LF, Magalhães CAS, Carneiro DNM (2009) Growth and production of soybean grains under different doses and phosphorus sources in different soils. Sci Agrotec. 33: 1220-1227.

Soares I, Lima SC, Crisóstomo LA (2007) Growth and mineral composition of soursop seedlings in response to phosphorus rates. J Sci Agro. 38: 343-349.
Sousa DMG, Lobato E, Rein TA (2004) Fertilization with phosphorus. In: Sousa A DMG.; Lobato E. (Ed.). Cerrado: soil correction and fertilization. 2. Ed. Brasília, DF: Embrapa Technological Information, pp.147-168.

Swiader JM, Chyan Y, Freiji, FG (1994) Genotypic differences in nitrate uptake and utilization efficiency in pumpkin hybrids. J Plant Nut. 17: 1687-1699.

Teodoro RB, Oliveira FL, Silva DMN, Fávero C, Quaresma MAL (2011) Agronomic aspects of leguminous to green fertilization in the cerrado of the high Jequitinhonha valley. J Sci Soil. 35:635-643. 